\title{
PENGARUH MODEL PEMBELAJARAN SNOWBALL THROWING DENGAN MEDIA ROLLING BALL GAME TERHADAP MOTIVASI BELAJAR SISWA BERBASIS DARING DALAM PEMBELAJARAN IPS PADA KELAS VIII SMP N 33 SEMARANG
}

\author{
Dyah Ayu Sagita Putri, Asep Ginanjar ${ }^{\varpi}$ \\ Prodi Pendidikan Ilmu Pengetahuan Sosial, Fakultas Ilmu Sosial, Universitas Negeri Semarang, Indonesia
}

\begin{abstract}
Info Artikel Abstrak
Sejarah Artikel:

Disubmit: Januari 2021

Direvisi: Februari 2021

Diterima: Maret 2021

Keywords:

Snowball Throwing,

Rolling Ball Game,

Learning Motivation,

Pada era global menuntut dunia pendidikan untuk selalu menyesuaikan dan mengikuti dalam penggunaan model dan media yang bervariasi dan kreatif bagi dunia pendidikan Tujuan penelitian ini adalah untuk mengetahui pengaruh model pembelajaran snowball throwing dengan media rolling ball game terhadap motivasi belajar siswa berbasis daring dalam pembelajaran IPS pada kelas VIII SMP N 33 Semarang. Metode yang digunakan dalam penelitian ini yaitu kuantitatif. Hasil dari penelitian ini adalah (1) Pelaksanaan pembelajaran menggunakan model pembelajaran snowball throwing dan media rolling ball game di SMP N 33 Semarang. (2) Penggunaan model pembelajaran snowball throwing dan media rolling ball game dapat memberikan pengaruh terhadap motivasi belajar siswa pada pembelajaran IPS. (3) Terdapat kendala yaitu pada hardware seperti handphone atau laptop yang tersedia dan jaringan internet yang tidak stabil saat kegiatan pembelajaran berlangsung.
\end{abstract}

\begin{abstract}
In the global era, it's requires the world education to always adjust and follow technological development to improve the quality of education, especially are used of varied and creative models and media for education, especially in the learning process. The purpose of this study was to determine the effect of the snowball throwing learning model with rolling ball game media on online-based student's learning motivation in social education at class of VIII SMP N 33 Semarang. The method used in this research is quantitative. The results of this study are (1) The learning implementation uses the snowball throwing learning model and the rolling ball game media at SMP N 33 Semarang. (2) The use of the snowball throwing learning model and the rolling ball game media can have an influence on student learning motivation in social studies learning. (3) There are obstacles, namely the available hardware such as cellphones or laptops and unstable internet networks during learning activities.
\end{abstract}

\begin{tabular}{lc}
\hline Alamatkorespondensi: & E-ISSN 2685-4929 \\
Gedung C1, Lantai 1, FIS Unnes & \\
Kampus Sekaran, Gunungpati, Semarang, 50229 & \\
Email:asep.ginanjar@mail.unnes.ac.id. & \\
\hline
\end{tabular}




\section{PENDAHULUAN}

Peranan guru sangat penting dalam proses pembelajaran, serta memajukan dunia pendidikan. Pendidikan adalah usaha sadar untuk menyiapkan siswa melalui kegiatan pengajaran untuk mempersiapkan kehidupan yang akan datang. Kualitas siswa dalam dunia pendidikan sangat bergantung pada peranan guru. Sistem pendidikan di Indonesia sedang mengalami tantangan baru yang disebabkan karena adanya wabah virus Covid-19, yang menyebabkan seluruh sistem pembelajaran dilembaga pendidikan dialihkan kepada metode pembelajaran online atau dalam jaringan (daring). Adanya gangguan dalam proses pembelajaran menyebabkan terjadinya beberapa perubahan terhadap peserta didik yang akhirnya berpengaruh terhadap motivasi belajarnya. Akibatnya pemerintah harus bekerja sama untuk menekan laju penyebaran virus Covid-19 dengan mengeluarkan kebijakan agar seluruh warga masyarakat untuk melakukan social distancing atau menjaga jarak. Sehingga dengan adanya kebijakan tersebut seluruh aktivitas masyarakat yang dulu dilakukan di luar rumah dengan berkumpul dan berkelompok, kini harus diberhentikan sejenak dan digantikan dengan beraktivitas di rumah masing-masing. Berdasarkan observasi yang telah dilakukan peneliti di SMP N 33 Semarang. Bahwa dalam kegiatan pembelajaran yang dilakukan oleh guru IPS pada kelas VIII dalam proses pembelajaran masih didominasi oleh guru, dan metode pembelajaran yang digunakan cenderung memakai metode ceramah. Selain itu guru kurang bervariasi model yang digunakan dalam menyampaikan materi. Sehingga siswa kurang termotivasi untuk belajar dan siswa kurang menguasai materi yang diajarkan. Menurut Arif Purnomo, dkk $\quad(2018: 144)$ problema pembelajaran IPS masih dipengaruhi oleh sebagian besar guru IPS belum terampil menggunakan beberapa model mengajar seperti cooperative learning, inquiry atau dengan menggunakan pendekatan perspektif global misalnya. Dalam proses belajar mengajar IPS masih dilakukan dalam bentuk pembelajaran konvensional, sehingga siswa hanya memperoleh hasil secara fatual saja, dan tidak mendapat hasil proses.

Motivasi belajar yang timbul pada diri siswa dalam kegiatan pembelajaran di kelas akan memberikan pengaruh yang besar dalam mencapai tujuan pembelajaran. Model Pembelajaran Snowball Throwing menurut Komalasari (2011:67) menyatakan bahwa, "Snowball Throwing adalah model pembelajaran yang menggali potensi kepemimpinan siswa dalam kelompok dan keterampilan membuat menjawab pertanyaan yang dipadukan melalui permainan imajinatif membentuk dan melempar bola salju". Media Rolling Ball Game media pembelajaran yang membuat kegiatan pembelajaran akan lebih menyenangkan bagi peserta didik untuk lebih giat dalam kegiatan pembelajaran.

Rumusan masalah dalam penelitian ini adalah: 1) Bagaimana pelaksanaan pembelajaran Snowball Throwing dengan menggunakan media Rolling Ball Game terhadap motivasi belajar siswa berbasis daring dalam pembelajaran IPS di SMP N 33 Semarang 2) Bagaimana kendala yang dihadapi dalam penggunaan model pembelajaran Snowball Throwing dengan media Rolling Ball Game berbasis daring untuk meningkatkan motivasi belajar siswa di SMP N 33 Semarang 3) Apakah penggunaan model pembelajaran Snowball Throwing dengan media Rolling Ball Game dapat meningkatkan motivasi belajar siswa berbasis daring dalam pelaksanaan pembelajaran IPS di SMP N 33 Semarang.

Penelitian ini bertujuan untuk: 1) Untuk mengetahui pembelajaran Snowball Throwing dengan menggunakan media Rolling Ball Game berbasis daring terhadap motivasi belajar siswa di SMP N 33 Semarang 2) Untuk mengetahui kendala yang dihadapi dalam menggunakan model pembelajaran Snowball Throwing dengan media Rolling Ball Game berbasis daring untuk meningkatkan motivasi siswa di SMP N 33 Semarang 3) Untuk mengetahui kendala yang dihadapi dalam menggunakan model pembelajaran Snowball Throwing dengan media Rolling Ball Game berbasis daring untuk meningkatkan motivasi siswa di SMP N 33 Semarang. 


\section{METODE}

Penelitian ini menggunakan metode kuantitatif menggunakan Quasi Experimenntal Design dengan pola Nonequivalent Control Group Design. Penelitian ini berdasarkan Sukardi (2010:63) Teknik memilih sampel yang termasuk nonprobabilitas adalah memilih sampel dengan dasar tujuan.

Populasi dalam penelitian ini adalah seluruh hasil belajar perserta didik kelas VIII SMP N 33 Semarang yang terdiri dari sembilan kelas, dengan jumlah 288 siswa. Sampel dalam penelitian ini diperoleh dua kelas yaitu kelas VIII A sebagai kelas eksperimen dan kelas VIII B sebagai kelas kontrol, teknik pengambilan sampel dalam penelitian ini adalah menggunakan teknik purpose sampling. Variabel bebas dalam penelitian ini yaitu model pembelajaran snowball throwing dengan media rolling ball game. Variabel terikat dalam penelitian ini adalah motivasi belajar siswa kelas VIII SMP N 33 Semarang.

Intrumen dalam penelitian ini terdiri dari pretest dan posttest. Teknik pengumpulan data menggunakan Observasi, Angket, Dokumentasi, Tes dan Wawancara. Person dalam Arikunto (2006:213) mengemukakan rumus untuk mengukur validitas butir soal yang dikenal dengan rumus product moment yaitu:

$$
\mathrm{r}_{\mathrm{x} \gamma}=\frac{\mathrm{N} \Sigma \mathrm{XY}-(\Sigma \mathrm{X})(\Sigma \mathrm{Y})}{\left.\sqrt{\left\{\mathrm{N} \Sigma \mathrm{X}^{2}\right.}-(\Sigma \mathrm{X})^{2}\right\}\left\{\mathrm { N } \Sigma \left\{\mathrm{N} \Sigma \mathrm{Y}^{2}-\left(\Sigma \mathrm{X}^{2}\right\}\right.\right.}
$$

Berdasarkan uji validitas yang telah dilakukan dapat dilihat hasil perhitungan uji validitas instrument adalah sebagai berikut:

Tabel 1. Hasil Uji Validitas Soal

\begin{tabular}{|l|l|l|}
\hline $\begin{array}{l}\text { Kriteri } \\
\text { a } \\
\text { Soal }\end{array}$ & Nomer Soal & $\begin{array}{l}\text { Jumla } \\
\text { h } \\
\text { Soal }\end{array}$ \\
\hline Valid & $\begin{array}{l}1,2,5,8,9,10,13,16,17,19 \\
, 21,22,24,25,26,28,32,33 \\
, 35\end{array}$ & 20 \\
\hline $\begin{array}{l}\text { Tdk } \\
\text { Valid }\end{array}$ & $\begin{array}{l}3,4,6,7,11,12,14,15,18,2 \\
0,23,27,29,30,31,34,37,3 \\
9,40\end{array}$ & 20 \\
\hline
\end{tabular}

Sumber: Data Primer 2020

Untuk menentukan tingkat reliabilitas tes digunakan metode tes. Perhitungan uji relibilitas dengan menggunakan rumus:

$$
r_{11}=\left(\frac{k}{k-1}\right)\left(1-\frac{\sum \alpha_{b}}{\alpha_{t}}\right)
$$

Berdasarkan perhitungan diketahui bahwa nilai alpha Cronbach yang dihasilkan oleh soal pilihan ganda sebesar 0,734 analisis data dalam penelitian ini menggunakan bantuan software statistic IBM SPSS 22.0 for Windows. Sedangkan untuk mengetahui tingkat kesukaran dan daya beda soal menggunakan bantuan aplikasi.

\section{HASIL DAN PEMBAHASAN}

\section{Penerapan Model Pembelajaran Snowball Throwing dengan Media Rolling Ball Game.}

Model pembelajaran snowball throwing dengan media rolling ball game yang dilakukan di kelas eksperimen VIII A SMP N 33 Semarang. Cara penerapan model pembelajaran Snowball Throwing dan media rolling ball game peneliti menyiapkan instrument berupa lembar pertanyaan wawancara yang diberikan ketika kegiatan eksperimen selesai dilakukan. Selain menggunakan lembar wawancara peneliti juga melakukan pengamatan ketika treatment berlangsung di kelas eksperimen, sebelum treatment peneliti menyiapkan beberapa perangkat pembelajaran seperti silabus, RPP, dan juga lembar pretest-postets pada guna mengukur perbedaan hasil belajar peserta didik, perangkat pembelajaran mampu diamati pada lampiran. Selain itu langkah-langkah yang mampu diamati dalam kegiatan di kelas eksperimen kemudian peneliti mencatat aspek-aspek yang mampu diamati. Melalui hasil pengamatan yang dilakukan oleh peneliti dapat ditarik beberapa hasil yaitu guru mampu menerapkan model pembelajaran Snowball Throwing dengan media Rolling Ball Game dengan baik, guru mampu melakukan langkah-langkah pembelajaran dengan kegiatan pembelajaran daring.

\section{Pengaruh Model Pembelajaran Snowball Throwing dalam Pembelajaran IPS Terhadap Kemampuan Guru.}

Berdasarkan penilaian kemampuan guru dalam mengelola kelas dapat disimpulkan bahwa kemampuan guru dalam mengelola pembelajaran 
IPS untuk kelas eksperimen mendapat kriteria sangat baik dengan jumlah 64 poin sedangkan untuk kelas kontrol mendapatkan jumlah poin 50. Selisih antara kelas eksperimen dan kelas kontrol 8 poin. Sehingga kemampuan guru dalam mengelola pembelajaran IPS lebih memberikan pengaruh di kelas eksperimen dengan pembelajaran model pembelajaran snowball throwing dengan media rolling ball game.

Aktivitas belajar peserta didik pada Berdasarkan hasil angket mengenai aktivitas siswa yang telah di isi menunjukkan aktivitas siswa kelas eksperimen tergolong sangat aktif. Hal ini terlihat dari kriteria aktifivitas siswa mengikuti pembelajaran IPS dengan presentase sebesar pada interval 39 - 48 dengan persentase $65 \%$ yang dikategorikan sedang saat kegiatan pembelajaran berlangsung. Sedangkan untuk kelas kontrol dari 32 siswa diantaranya berkriteria rendah sebesar 16 , sedang 12 , dan tinggi sebesar 4 siswa mengikuti pembelajaran dengan presentase $12 \%$ tinggi dan $38 \%$ sedang dan siswa lanya dengan presentase $50 \%$ rendah dalam mengikuti pembelajaran IPS.

Sehingga aktivitas siswa dalam pembelajaran IPS lebih efektif di kelas eksperimen dengan pembelajaran menggunakan model pembelajaran snowball trowing dengan media rolling ball game. Hasil belajar peserta didik diperoleh melalui kegiatan pretest serta posttest. Rekap skor hasil belajar peserta didik yang terdiri dari pretes dan posttes pada pembelajaran IPS dengan menggunakan model pembelajaran snowball throwing dengan media rolling ball game untuk kelas eksperimen sedangkan kelas kontrol dengan metode konvensional. Kelas control diketahui bahwa dari 32 siswa pada kelas kontrol ada yang tidak tuntas pada nilai pretest dan setelah pembelajaran selesai didapatkan 16 siswa lulus pada nilai posttest dan 16 siswa tidak tuntas pada nilai posttest. Sedangkan dari kelas eksperimen didapatkan 10 siswa tuntas pada nilai pretest dan 22 siswa tidak tuntas pada nilai posttest. Setelah diberikan model pembelajaran snowball throwing dengan media rolling ball game didapatkan 28 siswa tuntas pada nilai posttest dan 4 siswa tidak tuntas pada nilai posttest. Berdasarkan pada kelas kontrol VIII B dari 32 siswa diperoleh rata-rata (mean) sebesar 73,33 dengan simpangan baku (standart deviasi) sebesar 6,98 nilai minimum sebesar 60,00 nilai maksimum sebesar 85,0 . Sedangkan pada kelas eksperimen VIII A dari 32 siswa diperoleh rata-rata (mean) sebesar 80,00 dengan simpangan baku (standart deviasi) sebesar 7,13 nilai minimum sebesar 65,0 nilai maksimum sebesar 95,0. Respon Siswa pada kelas ekperimen dari 32 siswa 30 siswa diantaranya memberikan respon setuju dengan presentase sebesar $93,75 \%$ dan 2 siswa lainnya dengan presentase $6,25 \%$ sangat setuju dengan penggunaan model pembelajaran snowball throwing dengan media rolling ball game pada pembelajaran IPS.

Interpretasi data diatas, untuk lebih jelasnya, respon siswa kelas eksperimen terhadap model pembelajaran snowball throwing dengan media rolling ball game yang diberikan dapat dilihat pada gambar grafik berikut:

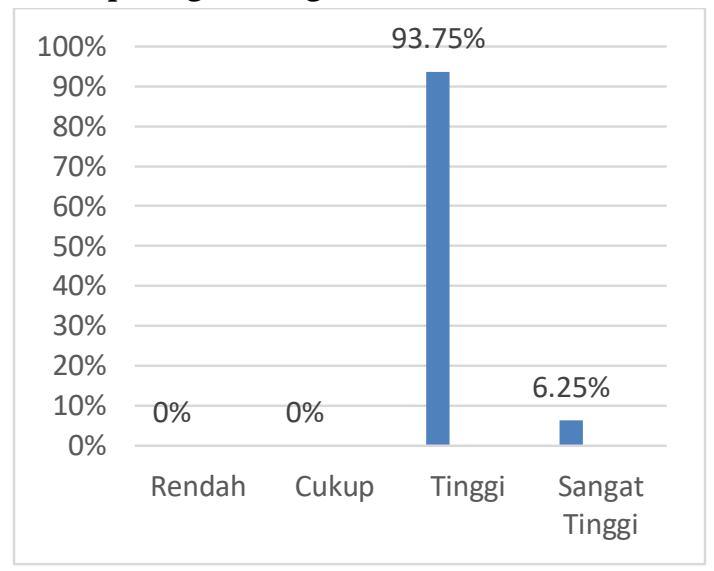

Gambar 1. Respon Kelas Eksperimen Sumber: Data Penelitian 2020

\section{PEMBAHASAN}

\section{Pelaksanaan Model Pembelajaran Snowball Throwing dengan Media Rolling Ball Game.}

Melalui hasil pengamatan yang dilakukan oleh peneliti dapat ditarik beberapa kesimpulan yaitu guru mampu menerapkan model pembelajaran snowball throwing dengan media rolling ball game dengan baik, guru mampu melakukan langkah-langkah pembelajaran dengan menggunakan pembelajaran secara daring. Dalam kegiatan penerapan model pembelajaran secara virtual guru juga sudah mampu melakukan pembelajaran dengan baik, dari mulai menyiapkan peralatan yang terdiri dari leptop dan, materi pembelajaran yaitu interaksi 
keruangan dalam kehidupan Negara-negara ASEAN memanfaatkan alokasi waktu, menyiapkan sumber dan media belajar, serta mengondisikan kelas.

Walaupun guru disini baru pertama kali menerapkan model pembelajaran snowball throwing dengan menggunakan media rolling ball game guru mencoba untuk profesional dan menyiapkan beberapa hal dengan tenang. Hal yang pertama guru lakukan adalah dengan mengondisikan peserta didik agar siap menerima pembelajaran, menyiapkan sumber belajar yang biasa digunakan yaitu buku dan power point yang mencakup pembelajaran, dan mengefektivikan alokasi waktu yang tersedia dan tidak segan untuk memulai pembelajaran pada jadwal yang telah disediakan.

\section{Pengaruh penggunaan Model Pembelajaran Snowball Throwing dengan Media Rolling Ball Game dalam Meningkatkan Motivasi Belajar Siswa}

Menurut Kamus Besar Bahasa Indonesia (2005: 849), pengaruh adalah daya yang ada atau timbul dari sesuatu (orang atau benda) yang ikut membentuk watak, kepercayaan atau perbuatan seseorang.

Kemampuan dalam mengelola pembelajaran ini yang diamati guru IPS kelas VIII SMP N 33 Semarang, skor penilaian dalam mengelola pembelajaran terbagi menjadi 4 kriteria yaitu: rendah, cukup, tinggi, dan sangat tinggi. Masing-masing kriteria memiliki skor mulai dari skor rendah (1), skor cukup (2), skor tinggi (3), dan skor sangat tinggi (4).

Kegiatan pembelajaran dilakukan dengan menyampaikan tujuan pembelajaran secara jelas, dan kemudian memberikan materi pembelajaran sesuai dengan model dan media yang akan digunkan dalam penelitian. Pembelajran menggunakan model pembelajaran snowball throwing dengan media rolling ball game siswa akan dibagi menjadi 4 kelompok, dimana 1 kelompok terdiri dari 8 siswa. Pembagian kelompok dipilih oleh guru dan peneliti dengan pertimbangan siswa yang mempunyai handphone atau laptop karena tidak semua siswa memiliki dan terkendala di jaringan internet yang tidak stabil.

Berdasarkan penilaian dari guru IPS kelas kontrol hasil penjabaranya adalah sebagai berikut: indikator pertama yaitu kegiatan pendahuluan mendapatkan skor 10 . Indikator kedua adalah kegiatan inti mendapatkan skor 30 . Indikator ketiga yaitu kegiatan penutup mendapatkan skor 10. Berdasarkan penjumlahan dari ketiga indikator didapatkan hasil akhir atau skor total 50 skor, penilaian mulai dari kelengkapan perangkat pembelajaran yang sesuai tidaknya dengan apa yang disampaikan sampai dengan bagaimana guru menyampaikan pembelajaran di dalam kelas daring. Sehingga dapat disimpulkan bahwa pengelolaan guru dalam proses pembelajaran IPS di kelas kontrol dikatakan cukup baik.

Untuk kelas eksperimen penilaian dari guru IPS kelas VIII hasil penjabarannya adalah sebagai berikut: indikator pertama yaitu kegiatan pendahuluan mendapatkan skor 10. Indikator kedua adalah kegiatan inti mendapatkan skor 43 Indikator ketiga yaitu kegiatan penutup mendapatkan skor 11. Berdasarkan penjumlahan dari ke-tiga indikator didapatkan hasil akhir atau skor total 64 skor, penilaian mulai dari kelengkapan perangkat pembelajaran yang sesuai tidaknya dengan apa yang disampaikan sampai dengan bagaimana guru menyampaikan pembelajaran di dalam kelas. Sehingga dapat disimpulkan bahwa pengelolaan guru dalam proses pembelajaran IPS dengan media pembelajaran dikatakan baik.

Aktivitas Belajar Peserta Didik. Indikator yang dijadikan dasar penilaian aktivitas belajar peserta didik diantaranya membaca, mendengar, menulis, bertanya dan berdiskusi yang kemudian terbagi ke beberapa aspek pernyataan. Beberapa aspek pernyataan tersebut digunakan sebagai acuan dalam melakukan pengamatan ketika pelaksanaan kegiatan pembelajaran dengan model pembelajaran snowball throwing dengan media rolling ball game untuk kelas eksperimen sedangkan kelas kontrol dengan metode konvensional ceramah pada pembelajaran IPS kelas VIII A dan VIII B pada materi interakasi keruangan dalam kehidupan negara-negara ASEAN.

Setelah mendapatkan data dari hasil penilaian aktivitas belajar peserta didik tersebut maka data tersebut diakumulasikan dan dibentuk interval nilai sesuai dengan hasil yang didapatkan serta kriteria berdasarkan interval tersebut yaitu 
mulai dari 19 - 28 mempunyai arti sangat rendah, 29 - 38 rendah, 39 - 48 sedang, 49 - 58 tinggi dan 58 - 68 yaitu sangat tinggi. Proses penilaian aktivitas belajar peserta didik diamati oleh guru mata pelajaran IPS serta diberikan nilai sesuai dengan aspek yang telah tercantum. Hal ini terlihat dari 32 siswa, 3 orang aktif mengikuti pembelajaran IPS dengan presentase sebesar 10 $\%$, dan 21 siswa dengan persentase $65 \%$ siswa 8 siswa rendah dengan presentase $25 \%$.

Sedangkan kelas kontrol aktivitas siswa kelas kontrol. Hal ini terlihat dari 32 siswa, diantaranya memiliki kriteria rendah sebesar 16 , sedang sebesar 12, dan tinggi sebesar 4 siswa mengikuti pembelajaran dengan presentase sebesar $12 \%$ tinggi dan $38 \%$ sedang dan siswa lainnya dengan presentase sebesar 50\% rendah dalam mengikuti pembelajaran IPS yang disampaikan dengan menggunakan metode konvensional.

Berdasarkan kesimpulan data diatas dari aktivitas belajar siswa kelas eksperimen dengan kelas kontrol memiliki perbedaan kelas eksperimen aktivitas belajar siswa tertinggi pada interval sedang di antara 39-48 yang mencapai 21 siswa sedangkan kelas kontrol memiliki aktivitas belajar siswa tertinggi pada interval rendah di antara 29-38 mencapai 16 siswa dan dapat disimpulkan di kelas ekpreriman yang aktivitas belajar siswa efektif dan penggunaan model pembelajaran snowball throwing dengan media rolling ball game dapat mempengaruhi motivasi belajar siswa.

Hasil belajar dapat dilihat dari pengujian hipotesis terkait hasil belajar peserta didik dilakukan melalui pelaksanaan uji pretest dan posttest untuk mengetahui adanya peningkatan nilai setelah dilaksanakan pembelajaran IPS dengan menggunakan model pembelajaran snowball throwing dengan media rolling ball game dan yang menggunakan metode konvensional. Peningkatan atau perbedaan hasil pretest dan posttest peserta didik dilakukan melalui perhitungan uji perbedaan rata-rata/uji t. Melalui perhitungan uji $t$ atau uji perbedaan rata-rata yang telah dihitung, diketahui bahwa nilai pretest dan posttest mengalami peningkatan yang signifikan.

Pada kelas eksperimen dari pelaksanaan pretest yaitu peserta didik dari kelas eksperimen yaitu kelas VIII A mendapatkan nilai tertinggi yaitu 80 sebanyak 1 peserta didik, nilai terendah yaitu 45 sebanyak 1 peserta didik. Pada pelaksanaan pretest ini jumlah peserta didik yang berhasil mencapai batas tuntas mata pelajaran IPS atau KKM hanya berjumlah 10 orang dari 32 peserta didik dan yang tidak mencapai KKM sebanyak 22 peserta didik, rata-rata yang didapatkan secara keseluruhan dari hasil pretest kelas eksperimen yaitu 67,5. Terdapat peningkatan yang signifikan dari hasil sebelumnya.

Sedangkan pada kelas kontol yaitu VIII B yang dapat mencapai KKM hanya berjumlah 7 orang dari 32 peserta didik dan yang tidak mencapai KKM sebanyak 25 peserta didik, ratarata yang didapatkan dari nilai pretest secara keseluruhan dari kelas kontrol 61,5. Setelah pelaksanaan posttest peserta didik yang dapat mencapai ketuntasan KKM pada kelas kontrol yaitu kelas VIII B yang dapat mencapai ketuntasan KKM sebanyak 7 peserta didik dan 25 lainnya belum mencapai KKM.

Hasil belajar di masing-masing kelas mengalami perubahan yang baik dan hasil belajar meningkat. Hasil belajar di kelas eksperimen menunjukkan perubahan nilai dengan rata-rata pretest sebesar 67,5 dan rata-rata posttest sebesar 82,6 . Kelas kontrol juga menunjukkan perubahan nilai dengan rata-rata pretest 61,5 dan rata-rata posttest sebesar 73,5. sehingga dapat disimpulkan bahwa rata-rata hasil belajar siswa yang diajar menggunakan model pembelajaran snowball throwing dengan media rolling ball game lebih tinggi daripada rata-rata hasil belajar siswa yang diajar menggunakan metode konvensional.

Respon peserta didik dapat dilihat dengan Angket yang digunakan untuk mengetahui respon peserta didik didalamnya terdapat 4 kriteria yaitu sangat tinggi, tinggi, sedang, rendah. Keempat kriteria tersebut memiliki skor yaitu skor 1 untuk jawaban tidak setuju, skor 2 untuk jawaban cukup skor 3 untuk jawaban setuju, dan skor 4 untuk jawaban sangat setuju. Pernyataan yang diberikan kepada peserta didik berjumlah 20 butir pernyataan untuk mengukur kemampuan analisis peserta didik. Agar dapat dicapai skor maksimal.

Setelah didapatkan penjumlahan secara keseluruhan dari data respon dari setiap peserta 
didik tersebut yang menunjukkan bahwa skor rata-rata kelas VIII A terdapat pada interval 5165 ,dapat dikategorikan bahwa peserta didik setuju apabila pembelajaran IPS menggunakan model pembelajaran snowball throwing dengan media rolling ball game terhadap motivasi belajar peserta didik pada materi pelajaran interaksi keruangan dalam kehidupan Negara-negara ASEAN. Peserta didik merasa senang apabila pembelajaran tersebut menggunakan model pembelajaran snowball throwing dengan media rolling ball game sehingga menjadikan peserta didik lebih fokus dalam mengikuti pembelajaran yang berlangsung. Sedangkan pada keterampilan siswa dapat diketahui bahwa rata-rata skor keterampilan siswa saat pembelajaran dari ke 32 siswa adalah 60,91 . Adanya keterkaitan antara variabel $\mathrm{X}$ dan $\mathrm{Y}$ dimana dengan menggunakan model pembelajaran snowball throwing dengan media rolling ball game peserta didik merasa senang dan menyukai model pembelajaran yang inovatif dan interaktif yang kemudian berdampak kepada motivasi belajar siswa yang membaik dan mudah memahami materi khususnya materi interaksi keruangan dalam kehidupan Negara-negara ASEAN. Berdasarkan hasil pembahasan di atas dapat disimpulkan bahwa penelitian mengenai pengaruh penggunaan model pembelajaran snowball throwing dengan media rolling ball game terhadap motivasi belajar peserta didik pada mata pelajaran IPS kelas VIII SMP N 33 Semarang dapat dikatakan memberikan pengaruh terhadap motivasi belajar siswa yang telah terpenuhi dan tercapai.

\section{Kendala dalam Penerapan Model Pembelajaran Snowball Throwing dengan Media Rolling Ball Game.}

Media pembelajaran rolling ball game yang merupakan media pembelajaran berupa quiz dapat membantu peserta didik dalam memahami materi IPS khususnya materi interaksi keruangan dalam kehidupan Negara-negara ASEAN. Pihak guru yang yang menerapkan model pembelajaran snowball throwing sendiri merasa tertantang untuk menerapkan sebab baru pertama kali dilakukan dengan cara virtual dan tidak merasa keberatan untuk mempelajari cara menerapkan aplikasi zoom guna melengkapi model pembelajaran snowball throwing dengan media rolling ball game. Kendala yang dihadapi oleh guru yaitu Bu Dra. Purnamawati sendiri yaitu lebih berfokus pada jaringan internet karena pembelajaran bergantung pada signal internet dan kuota internet sehingga pihak sekolah memberikan subsidi kuota kepada para siswa untuk digunakan dalam kegiatan pembelajaran daring, baik dari guru maupun para peserta didik yang mengikuti pembelajaran secara daring di rumah masingmasing.

Sehingga dalam penerapan model pembelajaran snowball throwing dengan media rolling ball game pada mata pelajaran IPS membutuhkan waktu yang cukup lama untuk menyiapkan para siswa sebelum kegiatan berlangsung dengan memberikan kata sandi kelas dan tak semua siswa langsung merespon guru dan peran guru sangat besar dalam mengondisikan para siswa untuk masuk kedalam kelas online. Kendala lainnya yaitu peserta didik menjadi riuh dan terlalu bersemangat saat memulai mengikuti pembelajaran sehingga keadaan peserta didik menjadi kurang kondusif. Kendala yang dialami pihak peserta didik sendiri yaitu terdapat beberapa peserta didik yang memiliki kesulitan dalam penggunaan aplikasi zoom dan signal internet yang tidak stabil, sehingga siswa yang memiliki kesulitan, guru memberi pengarahan untuk dapat masuk dalam kelas pembelajaran dengan lancar dan kondusif.

\section{SIMPULAN}

Berdasarkan hasil penelitian dan pembahasan dapat ditarik kesimpulan sebagai berikut:

Pelaksanaan pembelajaran menggunakan model snowball throwing dan media rolling ball game di SMP N 33 Semarang dalam Pelaksanaan pembelajaran snowball throwing dengan media rolling ball game terhadap motivasi belajar siswa berbasis daring dalam pembelajaran IPS di SMP N 33 Semarang dari hasil penelitian dapat disimpulkan bahwa pelaksanaan pembelajaran berjalan lancar dapat dilihat dari kemampuan guru dalam mengelola pembelajaran IPS untuk kelas eksperimen mendapat kriteria tinggi dengan jumlah poin 64 sedangkan untuk kelas kontrol mendapatkan jumlah poin 50 dengan mendapat kriteria cukup. Selisih antara kelas 
eksperimen dan kelas kontrol 14 poin. Sehingga kemampuan guru dalam mengelola pembelajaran IPS lebih memberikan motivasi belajar di kelas eksperimen dengan pembelajaran menggunakan model pembelajaran snowball throwing dengan media rolling ballgame.

Penggunaan model pembelajaran snowball throwing dengan media rolling ball game dapat meningkatkan motivasi belajar siswa disaat kegiatan pembelajaran daring di SMP N 33 Semarang, berdasarkan hasil penelitian dapat disimpulkan bahwa penggunaan model dan media memberikan pengaruh bagi motivasi siswa dilihat dari aktivitas peserta didik dalam pembelajaran IPS untuk kelas eksperimen mendapat kriteria sedang pada interval 39-48 dengan presentase $65 \%$ sedangkan untuk kelas kontrol mendapat kriteria rendah pada interval 29-38 dengan presentase $50 \%$. Sehingga aktivitas siswa dalam pembelajaran IPS lebih efektif di kelas eksperimen dengan menggunakan model pembelajaran snowball throwing dengan media rolling ballgame.

Nilai rata-rata pretest kelas kontrol sebesar 61,67 dan kelas eksperimen sebesar 67,26 ratarata nilai pretest kelas eksperimen lebih besar dari rata-rata nilai kelas kontrol. Untuk rata-rata nilai posttest pada kelas kontrol sebesar 73,33 sedangkan kelas eksperimen sebesar 80,00, ratarata nilai posttest kelas eksperimen lebih besar dari rata-rata kelas kontrol, sehingga dapat disimpulkan bahwa hasil belajar siswa yang diajar menggunakan model snowball throwing dengan media rollingball game lebih meningkat daripada kelas yang tidak menggunkan model dan media atau menggunakan metode konvensional.

Kendala yang dalam hadapi dalam kegiatan pembelajaran IPS pada kelas VIII di SMP N 33 Semarang seperti dalam kegiatan pembelajaran secara daring menyebabkan adanya kendala dalam hal penggunaan alat komunikasi jarak jauh, siswa mengeluhkan jaringan yang tidak stabil yang membuat kegiatan pembelajaran menjadi sedikit terganggu dan kegiatan pembelajaran dilakukan di rumah masing-masing sehingga kurang kondusif siswa kurang disiplin di saat pembelajaran berlangsung siswa kurang disiplin sehingga guru harus berperan aktif dalam mengondisikan siswa untuk dapat mengikuti pembelajaran secara daring dengan baik. Peranan guru sangat besar disaat kegiatan pembelajaran jarak jauh karena mengondisikan siswa sangatlah tidak mudah dan diharapkan siswa juga mengerti dan memahami pentingnya kegiatan pembelajaran di tengah pandemi.

\section{DAFTAR PUSTAKA}

Adi, Widi Cahya, and Mochammad Iqbal. "Pengembangan Virtual Laboratory pada Pokok Bahasan Sistem Ekskresi dalam Meningkatkan Motivasi Belajar Siswa Kelas XI." (2015).

Asyar, Rayandra. 2012. Kreatif Mengembangkan Media Pembelajaran. Jakarta: Referensi.

Akhiriyah, Dewi Yuni. 2012. Penerapan Model Pembelajaran Snowball Throwing untuk meningkatkan Kualitas Pembelajaran IPS pada Siswa Kelas V SDN Kalibanteng Kidul 01 Semarang. Jurnal Kependidikan Dasar. Vol: 1, No:3 di unduh pada tanggal 16 Juni 2019 pukul 18:34 WIB.

Arikunto, S. 2006. Prosedur Penelitian Suatu Pendekatan Praktek. Jakarta: Rineka Cipta

Arikunto, Suharsimi.2009. Dasar-dasar Evaluasi Pendidikan. Jakarta: PT. Rineka Cipta.

Ferismayanti. 2020. Meningkatkan Motivasi Belajar Siswa pada Pembelajaran Online Akibat Pandemi Covid-19.Vol. 1, No:1 di unduh pada tanggal 1 November 2020 pikul 15.00 WIB.

Hamalik, Oemar. 2003. Psikologi Belajar Mengajar. Bandung: Sinar Baru Algensindo

Hamdayana, Jumanta. 2014. Model dan Metode Pembelajaran Kreatif dan Berkarakter. Bogor : Ghalia Indonesia.

Hamdani. 2011. Strategi Belajar Mengajar. Bandung: Pustaka Setia. 
Hasan Alwi, dkk. 2005. Kamus Besar Bahasa Indonesia. Jakarta: Departemen Pendidikan Nasional balai Pustaka

Himam, Muhammad Wafaul, et al. "Rolling Ball Game : Pengembangan Media Pembelajaran Keterampilan Berbicara Bahasa Arap Kelas VIII MTs di Kabupaten Pekalongan." Lisanul'Arab: Journal of Arabic Learning and Teaching 6.1 (2017): 50-55.

Komalasari, Kokom. 2011. Media Pembelajaran IPS. Bandung: Universitas Pendidikan Indonesia.

Loysiana, Arini. 2016. 'Tingkat Motivasi Belajar Siswa (Studi Diskriptif pada siswa kelas VI SD Maria Immaculata Cilacap Tahun Ajaran 2015/2016 dan Implementasinya Terhadap Penyusunan Topik Bimbingan Belajar'. Skripsi. Yogyakarta: Fakultas Keguruan dan Ilmu Pendidikan.

Maryani, Ika. 2016. Strategi LPTIK Pengembangan Kompetensi Pedagogik Calon Guru: Caraka Putra Bhakti. No. 2. Hal. 98

Nurdyansyah, dan Eni Fariyarul. 2016. Inovasi Model Pembelajaran. Sidoarjo: Nizamia Learning Center

Purnomo, Arif dkk. 2018. Merancang Pembelajaran IPS. Semarang: Cipta Prima Nusantara.

Pusdiklat Pegawai Kementerian Pendidikan dan Kebudayaan. "SURAT EDARAN MENDIKBUD NO 4 TAHUN 2020 TENTANG PELAKSANAAN KEBIJAKAN PENDIDIKAN DALAM MASA DARURAT PENYEBARAN CORONA VIRUS DISEASE (COVID-1 9)," 1 November2020. https://www.kemdikbud.go.id/main/blo g/2020/05/kemendikbud-terbitkanpedoman-penyelenggaraan-belajar-darirumah

Pradila, Tri Ririn. 2017. Peningkatan Hasil Belajar Matematika pada materi Himpunan Melalui
Penerapan Model Pembelajaran Kooperatif Tipe Snowball Throwing di kelas VII 2 SMP Swasta Nurul Hasanah. Skripsi: Universitas Islam Negeri Sumatra Utara.

Rosyidi, Abdul Wahab. 2009. Media Pebelajaran Bahasa Arab. Malang: UIN Malang Press.

Rimbarizki, R. 2017. Penerapan Pembelajaran Daring Kombinasi Dalam Meningkatkan Motivasi Belajar Peserta Didik paket C Vokasi di Pusat Kegiatan Belajar Masyarakat(PKBM). Karangayar: UNESA

Rusman. 2013.Model-model Pembelajaran (Mengembangkan Profesionalisme Guru). Depok: PT Rajagrafindo Persada.

Sapriya. 2009. Pendidikan IPS (Konsep dan Pembelajaran). Bandung: Rosda Karya

Sardiman, A.M. 1986. Interaksi \& Motivasi Belajar Mengajar. Jakarta: PT Rajagrafindo Persada.

Setyowati,Dewi Liesnoor. 2018. Panduan Penulisan Skripsi. Semarang : FIS UNNES.

Setyowati. 2017. Pengaruh Motivasi Belajar Terhadap Hasil Belajar Siswa Kelas VII SMPN 13 Semarang.

Setiawan, Iwan dkk. 2016. Buku Ilmu Pengetahuan Sosial. Jakarta: Kementrian Pendidikan dan Kebudayaan.

Shoimin, Aris. 2014. 68 Model Pembelajaran Inovatif dalam Kurikulum 2013. Yogyakarta: AR-RUZZ MEDIA.

Sugiyono. 2006. Metode Penelitian Kualitatif Kuantitatif $R \& D$. Bandung: Alfa Beta

Sugiyono.2013. Metode Penelitian Kualitatif Kuantitatif R\&D. Bandung: Alfa Beta

Sugiyono. 2016. Metode Penelitian Kualitatif Kuantitatif R\&D. Bandung: Alfa Beta

Sudjana, Nana.2002. Metode Statistika Edisi keenam. Bandung: Tarsito 
Sukmadinta, Syaodih Nana. 2009. Metode Penelitian Pendidikan. Bandung: PT Remaja Rosdakarya Offset.

Sumiati. 2014. Upaya Meningkatkan Hasil Belajar PAI IAIN SU Melalui Penerapan Strategi Pembelajaran Kooperatif Model Snowball Throwing Materi Ketentuan-ketentuan Puasa Rahmadan di kelas V SDN Manis. Skripsi: IAIN Sumatera Utara.
Sukardi. 2010. METODOLOGI PENELITIAN PENDIDIKAN (Kompetensi dan Praktiknya). Jakarta: Bumi Aksara.

Susilawati, \& Rustati, I. 2013. Pembelajaran dan Evaluasi Hasil Belajar IPS. Program S1 UPI Kampus Serang.

Trianto. 2010. Model Pembelajaran Terpadu:Konsep,strategi,dan impletasinya dalam Kurikulum. Jakartya: Bumi Aksara

Widayati, Sri Ninik dan Hafis. 2012. Model-model Pembelajaran Inovatif. Surabaya: Garuda Mas Sejahtera 